\title{
A Review of Momentum Strategy in Capital Market
}

\author{
Ghazali Syamni ${ }^{1, *}$ Wardhiah ${ }^{2,}$ Devi Permata Sari ${ }^{3,}$ Badratun Nafis ${ }^{4}$ \\ ${ }^{1}$ Universitas Malikussaleh and PhD Studeng in PDIM, FEB Universitas Syiah \\ ${ }^{2}$ Universitas Malikussaleh and PhD Studeng in PDIM, FEB Universitas Syiah \\ ${ }^{3}$ FEB-Universitas Malikussaleh \\ ${ }^{4}$ FEB-Universitas Malikussaleh \\ *Corresponding author. Email: ghazali.syamni@unimal.ac.id
}

\begin{abstract}
This research is a literature research review that focuses on the topic of the momentum strategy in the capital market. This strategy is a trading strategy carried out by investors by buying stocks that have performed well in the hope that the performance will continue well in the future. The results of the study show that most of the capital market investors carried out a momentum strategy even though the implementation is still inconsistent. It indicates that the development of several capital markets leads to inefficient markets.
\end{abstract}

Keywords: a review, momentum, strategi, capital, market

\section{INTRODUCTION}

Since the era of the '60s before, researchers, academics, market players, and even students agree more that the conditions of the capital market are rational. The concept of investor rationality has been used as a pillar in market efficiency theory [1]. This rational capital market condition makes use of the theory of developing market efficiency in the financial research of [2]. In the efficiency theory, investors cannot take advantage because the price of securities is a reflection of all relevant information.

Furthermore, in its development, the level of rationality in the capital market has shifted slightly with the birth of financial behavior theory $(\mathrm{BF})$. The $\mathrm{BF}$ theory was born due to the phenomenon of investor trading behavior in the capital market that is not rational [3]. Investor irrationality appears on the trading behavior of investors who tend to deviate. The deviations committed by investors are closely related to the attitude of humans who cannot avoid using their emotions and psychology so that they allow investors to behave irrationally.

The use of emotional attitudes and investor behavior tends to lead to irrational behavior. One of the irrational behavior is the underreaction of investors. Underreaction is an attitude of investors who take the position that the group of stock portfolios they invest in in the long term remains in good standing. This attitude allows investors to hold on to the information they received previously [4]
This underreaction has prompted many investors to allocate funds to buy a group of portfolios that have performed well (winner) as an alternative to investing in the capital market. Because investors who purchase stock portfolios that are performing well (winner) expect the portfolio to be well in the future. The attitude of investors who buy this group of well-performing stock portfolios in a trading investment strategy in the capital market is called the momentum strategy.

A momentum strategy is a trading strategy carried out by investors in making transactions on the capital market. This strategy was first introduced by [5], who stated that investors carry out a momentum strategy in the capital market to get an abnormal return. The abnormal return obtained by investors is obtained by placing and buying groups of outstanding stocks and selling non-winning stock portfolios.

Based on the description above, this literature review aims to provide an understanding of the existence of a momentum strategy in the capital market. It is expected that this literature review will give some of the latest knowledge about momentum strategies in the capital market. Besides, it provides options for future researchers who take the topic of financial behavior that occurs in the capital market.

\section{METHOD}

It is a literature review research that analyzes journals or articles and current research literature regarding topics and issues in research related to 
momentum strategies. The results of this study are expected to provide insights, understanding, and knowledge to be developed in the problem of momentum strategy and contrarian strategy in several world capital markets.

\section{RESULTS}

In investing in the capital market, investors use their respective strategies. One of the strategies used by investors is the momentum strategy, where investors expect to keep getting abnormal returns in their transactions in the capital market using this momentum strategy.

The momentum strategy is a strategy carried out by investors when trading on an exchange that tends to buy stocks with good performance (winner) and sell stocks that are underperforming (loser). In other words, the existence or success of this momentum strategy occurs when investors get an abnormal return on their previously selected good performing stock portfolio.

Regarding this momentum strategy, several recent empirical studies have found inconsistent results. Inconsistencies vary, such as in terms of time, among investors, and the insignificant results. Some even say that the strategy moment tends to be small in various capital markets in the world.

\section{A. Current research on strategic momentum in the American and European capital markets}

Research in the Latin American region, [6] found that momentum strategies are possible in Latin American capital markets, and the significant abnormal returns of momentum strategies can be obtained by controlling for value, size, and market factors. However, when the controls are only carried out on the state, the momentum strategy is not significant.

A research on the American Stock Exchange conducted by [7] found no significant advantage over the use of the momentum strategy on the American Stock Exchange since the 1990s. They explained that the abnormal return was insignificant because the market tended to be efficient in addition to the reduced risk premium on macroeconomic variables.

Research in America using the Green Index data by [8] reveals that in the long term, the momentum strategy on the Green Index on the American Stock Exchange is still better, yet also states that momentum strategy is less effective. In another American study, [9] say that there is an indication of a consistent stock portfolio group. It means that a well-performing industrial sector portfolio tends to provide a sustainable average abnormal return. In contrast, the underperforming group of stock portfolios does not turn in the right direction.

Research in Germany by [10] reveals different results, and there is no indication of using a momentum strategy in the German capital market but rather a contrarian strategy. Even though they are not economically significant, they indicate that the German capital market tends to be efficient.

Furthermore, research conducted by forty countries in the world by [11] indicates that more than half of the countries sampled in their study receive positive abnormal returns and the rest get negative abnormal returns. So, they conclude that the capital market tends to be inefficient.

Research on the Spanish Exchange by [12] explained that there was a momentum strategy for twelve months and a contrarian strategy for sixty months. It means that the momentum strategy phenomenon occurs in 1 year or shorter than the contrarian strategy in 5 months.

Several studies conducted in the American region conclude that the use of momentum strategy in trading transactions on the American capital market is ineffective. There are even studies, which state that the use of momentum strategies in trading transactions on the American capital market is not significant. Meanwhile, research in Europe (Germany) does not find the existence of a monetary strategy carried out by investors in transacting on the capital market.

Finally, some of the research conclusions above conclude that capital markets in developed countries such as America and Europe are in two positions. The first position is to support the theory of financial behavior, where there is no momentum strategy applied in several exchanges. Also, it cannot be denied that the capital markets in the American and European regions tend to be efficient.

\section{A. Research on momentum strategies in Asian capital markets}

Research using six stock exchanges in Asian countries by [13] states that investing with an all-out momentum strategy does not provide significant returns when the return volatility is high. However, when carrying out a momentum strategy by normally investing in the six new Asian exchanges, it gives significant returns. According to them, investors need to limit things related to the specific factors of the company being invested in investing.

A study on the Indian capital market by [14] indicates that institutional foreign and domestic investors use a momentum strategy in the short-term, while individual (retail) investors use a contrarian strategy. The reason is that foreign investors use a momentum strategy because of the service factor from the industrial sector, and individual investors are more familiar with the conditions of companies in their countries.

A study on the Korean Stock Exchange by [15] on the momentum strategy found that individual investors underreaction, especially on large trade sizes that performed well during 2001s.d 2007, then weakened when measured in 1997-2007. Meanwhile, foreign 
investors carried out underreaction as a representation of the momentum strategy on small stock trading sizes and also on large stocks. They conclude that no stock will always stand up to its good performance.

Other research in Korea by [16] reveals that investing using a momentum strategy on the Korean Stock Exchange can be done. They conclude their findings after testing the momentum strategy using the Hidden Markov Model (HMM), where investors get better returns than the traditional approach. Another Korean Stock Research by [17] suggests that the momentum strategy abnormal return occurs for twelve months in the securities market. Finally, we recommend that the weekly momentum is closely related to speculative activity in the commodity futures market.

Research on the China Stock Exchange by [18] claimed that the momentum strategy did happen. Their findings provide a signal that investors trading in the Chinese capital market can carry out a momentum strategy to get their abnormal returns. The occurrence of the momentum phenomenon appears in the period of one formation then reverses in the next two periods. This research is almost the same as the research conducted by [19], which show that momentum strategies still provide profits in the medium-term then reverse in the long-term.

Another study in China conducted by [20] concludes that a portfolio of stocks with slower-growing institutional ownership is indicated to provide momentum to obtain high abnormal returns. Research by [20] suggests to buy stocks with low institutional ownership and sell a group of high-ownership stock portfolios

Furthermore, research on the Singapore Exchange conducted by [21] states that the occurrence of higher price momentum in the short-term and lasts into the long-term. This momentum occurs in small companies that are stable and have a good level of volatility. Meanwhile, research on the Iran Stock Exchange conducted by [22] claim that determining the price of a well-performing stock portfolio group is not a speculation but an irregularity in the capital market that must be managed in a trading strategy.

Based on the description of empirical research in various countries in Asia, it concludes that the existence of a momentum strategy in several capital markets in the Asian region is real. The existence of this momentum strategy occurs in different circumstances both from the test of the investor group, the size of the company, and the period of time for the test.

\section{A. Recent research on strategic momentum in the Indonesian capital market}

Recent research conducted in Indonesia by [23] reveals that both individual investors and large investors use a contrarian strategy and momentum strategy, and small investors trade more often with small frequency in the short-term, and big investors do not frequently but by trading large amounts over the long-term. Previously, [24] stated that both domestic investors and foreign investors trade using a contrarian strategy in large and medium-sized companies. But they tend to use the momentum strategy in the small stock portfolio group.

Research by [25] found that in a four-month and sixmonth period, the winner (good) performance stock portfolio groups gave superior returns because they could reduce risk. Other findings by [26] on using the LQ 45 Index, SETS 50 Thailand, and the Singapore Stock Exchange STI mentioned that the well-performed stock portfolio group produced significant and positive abnormal returns. On the other hand, the underperforming group of stock portfolios gives a negative and significant abnormal return on average.

Thus, they concluded that the momentum strategy could be carried out in IDX. Their results are in line with previous research conducted by [27], which states that applying a momentum strategy in trading on the stock exchange provides a better profit rate. But the results of another research conducted by [28] where they found that the trading strategy at IDX is better at using a contrarian strategy because it provides more profit for investors.

Based on descriptions of several studies in Indonesia, the investors in the Indonesia Stock Exchange have different trends. It means that investors have the opportunity to carry out a strategy that supports the momentum strategy in the Indonesian capital market, and some support a contrarian strategy by using efficient market strategies.

\section{CONCLUSION}

This research examines and discusses the existence of a momentum strategy that occurs in various capital markets in the world, including the Indonesia Stock Exchange. The momentum strategy is a strategy that investors use when investing or trading in the capital market. Investors who use the momentum strategy are indicated by the behavior of buying stock portfolios that have performed well with the expectation that their performance will remain good. Thus, they get a positive and significant abnormal return.

Based on the description of the literature described above, it turns out that there are several variations. In general, the findings in the literature review of this study show that in various capital markets in the world, both developed and developing countries, the momentum strategy occurs. The occurrence of such momentum strategies varies widely but mostly occurs in the short-term during at least the twelve months observation and testing period.

Besides, this literature review also finds that although the momentum strategy exists in one article of capital, it is not economically significant in obtaining abnormal returns. In the Indonesian context, it also finds 
that in addition to using momentum trading strategies, some investors also use contrarian strategies. From the findings of the literature review above, it indicates that the capital market has the potential to lead to inefficiency.

\section{AUTHORS' CONTRIBUTIONS}

The author would like to thank all the authors who have taken their respective positions so that this paper is finished. In general, the authors would like to thank the seminar participants who have provided suggestions and comments so that they can make this paper better

\section{ACKNOWLEDGMENTS}

The researchers are grateful to those who have helped in this research so that this research is perfect. Researchers also appreciate the Faculty of Economics and Business, Universitas Malikussaleh, and the Research and Service Institute for reviewing and improving this research to be perfect.

\section{REFERENCES}

[1] Ma, S. (2017). The efficiency of China's stock market: Routledge.

[2] Jones, C. P., Utama, S., Frensidy, B., Ekaputra, I. A., dan Budiman, R. U. (2009). Investment: Analysis and Management (An Indonesian Adaptation). Jakarta: Salemba Empat.

[3] Gupta, E., Preetibedi, P., dan Mlakra, P. (2014). Efficient Market Hypothesis V/S Behavioural Finance. IOSR Journal of Business and Management, 16(4), 56-6

[4] Rafik, A., dan Marizka, S. P. (2017b). Concurrent momentum and contrarian strategies: Evidence from Indonesia. Indonesian Capital Market Review, 9(2), 63-74.

[5] Jegadeesh, N., dan Titman, S. (1993). Returns to buying winners and selling losers: Implications for stock market efficiency. The Journal Of Finance, 48(1), 65-91.

[6] Berggrun, L., Cardona, E., \& Lizarzaburu, E. (2020). Profitability of momentum strategies in Latin America. International Review of Financial Analysis, 101502.
[7] Bhattacharya, D., Li, W. H., \& Sonaer, G. (2017). Has momentum lost its momentum?. Review of Quantitative Finance and Accounting, 48(1), 191218.

[8] Chakrabarti, G., \& Sen, C. (2020). Time series momentum trading in green stocks. Studies in Economics and Finance.

[9] Grobys, K., \& Kolari, J. (2020). On Industry Momentum Strategies. Journal of Financial Research, 43(1), 95-119

[10] Herberger, T. A., Horn, M., \& Oehler, A. Are intraday reversal and momentum trading strategies feasible? An analysis for German blue chip stocks. Financial Markets and Portfolio Management, 1-19.

[11] Imran, Z. A., Wong, W. C., \& Ismail, R. (2020). Momentum Effect all over the World. International Journal of Banking and Finance, 14, 75-93

[12] Forner, C., \& Marhuenda, J. (2003). Contrarian and momentum strategies in the Spanish stock market. European Financial Management, 9(1), $67-88$

13] Hameed, A., \& Kusnadi, Y. (2002). Momentum strategies: Evidence from Pacific Basin stock markets. Journal of financial research, 25(3), 383397

[14] Chhimwal, B., \& Bapat, V. (2020). Comparative Study of Momentum and Contrarian Behavior of Different Investors: Evidence from the Indian Market. Asia-Pacific Financial Markets, 1-35

[15] Lee, K. (2019). Price momentum in Korea and the effect of investors' trading. Journal of Derivatives and Quantitative Studies.

[16] Ryou, H., Bae, H. H., Lee, H. S., \& Oh, K. J. (2020). Momentum Investment Strategy Using a Hidden Markov Model. Sustainability, 12(17), 7031.

[17] Kwon, K. Y., Kang, J., \& Yun, J. (2020). Weekly momentum in the commodity futures market. Finance Research Letters, 35, 101306.

[18] Gao, Y., Guo, B., \& Xiong, X. (2020). Signed momentum in the Chinese stock market. PacificBasin Finance Journal, 101433

[19] Chen, T. Y., Chou, P. H., \& Yang, N. T. (2020). Momentum and reversals: Are they really separate phenomena? Finance Research Letters, 32 101102 
[20] Chuang, H. (2020). The impacts of institutional ownership on stock returns. Empirical Economics, 58(2), 507-533.

[21] Ali, S. R. M. (2020). Do momentum and reversal matter in the Singapore stock market?. AsiaPacific Journal of Accounting \& Economics, 1-17.

[22] Elhaei Sahar, M., Hejazi, R., Salehi, A. K., \& Moltafet, H. (2020). Stock Price Momentum Modeling: A Grounded Theory Approach. Advances in Mathematical Finance and Applications, 5(2), 1-17.

[23] Koesrindartoto, D. P., Aaron, A., Yusgiantoro, I., Dharma, W. A., \& Arroisi, A. (2020). Who moves the stock market in an emerging countryInstitutional or retail investors? Research in International Business and Finance, 51, 101061.

[24] Arroisi, A., \& Koesrindartoto, D. P. (2019). Domestic and Foreign Investor Dynamics in Indonesian Stock Exchange: Evidence from 10 Years High-Frequency Data. Indonesian Capital Market Review, 11(1)

[25] Pasaribu, R. B. (2019). Value at Risk of Momentum Investment Strategy: Indonesia's Liquid Stocks Portfolio. Jurnal Manajemen Indonesia, 19(1).

[26] Murhadi, W. R., \& Abrianto, D. Y. P. (2019), March). A Study on short momentum phenomenon. In 16th International Symposium on Management (INSYMA 2019). Atlantis Press.

[27] Liem, R. W. (2012). Momentum Investing Strategy in Idx: An Experiment. Journal of Applied Finance \& Accounting, 5(1), 71-109.

[28] Musnadi, S., Faisal, \& Majid, M. S. A. (2018). Overreaction and underreaction anomalies in the Indonesian stock market: a sectoral analysis. International Journal of Ethics and Systems. Vol.34 No.42, pp.442-457. https://doi.org/10.1108/IJOES-12-2017-0235 